\title{
Isolation and Study of Bacteriophages Specific Against Multidrug Resistant Salmonella spp. and Assessment of their Therapeutic Potential
}

\section{Khatuna Makalatia ${ }^{1,2}$, Elene Kakabadze ${ }^{1}$, Nino Grdzelishvili ${ }^{1}$, Nata Bakuradze ${ }^{1}$, Luka Sanikidze ${ }^{1}$, Nino Chanishvili ${ }^{1}$}

${ }^{1}$ Eliava Institute of Bacteriophage, Microbiology and Virology, 0162 Tbilisi,Georgia;elene.k akabadze@pha.ge,nata.bakuradze@pha.ge,n.grdzelishvili@pha.ge, n.chanishvhili@pha.ge

2 Faculty of Medicine, Teaching University Geomedi, 0114 Tbilisi, Georgia. khatuna.makalatia@geomedi.edu.ge Corresponding Author: Khatuna Makalatia, khatuna.makalatia@geomedi.edu.ge

\begin{abstract}
Within the scope of the study, clinical non-typhoidal Salmonella were isolated in Armenia and Georgia and identified based on conventional microbiological methods and MALDI-TOF MS. These isolates were further analysed by serotyping (White-Kauffmann-Le Minor scheme) and their antimicrobial susceptibility profiles were defined. A total of 40 antibiotic resistance profiles were identified, of which 35 were characteristic of clinical strains. Out of a total of 345 isolates, 238 strains from Georgia, Armenia and Ireland were eventually selected for our study. Using the strains of this collection, 13 new bacteriophages were isolated, characterized by biological and genetic features. Based on the data obtained, phages were classified and the peculiarities of their life cycle were determined (virulent-lytic, moderate-lysogenic).
\end{abstract}

Analysis of the sequencing results showed that only one of the 12 phages identified as temperate phage (vB_GEC_TR), it belongs to the family Podoviridae, genus-Laderbergvirus. While the other 11 phages are virulent, they are related to well-known and characterized phages, which are used in various phage preparations. Analysis of their genomes did not show any lysogeny associated genes. Among the virulent phages, 6 are members of Myoviridae family (vB_GEC_B1, vB_GEC_B3, vB_GEC_MG, vB_GEC_BS, vB_GEC_NS7, vB_GEC_7A) and 5 of the Syphoviridae family (vB_GEC_N5, vB_GEC_N8, vB_GEC_M4, vB_GEC_M5, vB_GEC_Hi). In vitro tests revealed that the phages - vB_GEC_B1, vB_GEC_BS, vB_GEC_B3, vB_GEC_NS7, vB-GEC-N8 showed high activity (60\% to 80\%) against the examined strains. The phages have been shown to be more effective against clinical strains $(\approx 90 \%)$ than against veterinary strains $(\approx 70 \%)$. The strains susceptible to these phages were mainly S.typhimurium and $S$. Enteritidis serovars and are largely of clinical origin. Based on our research we can conclude that the application of phages as an additional tool for the treatment of MDR Salmonella infections seems to be plausible. Phages are natural and specific antibacterial agents, which can lyse bacteria irrespective of their 
AMR status, whilst leaving the commensal microflora unharmed. This is one of the main advantages of phages in comparison to antibiotics. The phages tested in this study showed potential for application in phage therapy against MDR Salmonella infections.

Key words: bacteriophages, salmonella, bacteria, resistance to antibiotics.

\section{Introduction}

Salmonella is a ubiquitous, increasingly resistant bacterium which can survive several weeks in a dry environment and even several months in water. Infections caused by various salmonella pose a serious threat to both human and animal health. According to the World Health Organization's report (WHO), 550 million people are infected with diarrhea each year, including 220 million children under the age of five ${ }^{1}$. Salmonella is one of the leading causes of foodborne infections. Antibiotic resistance is a growing process in non-typhoid salmon and has been monitored since 19962. Since 2017, Fluoroquinolone-resistant Salmonella spp. was included in the list of high-priority pathogens by the World Health Organization $(\mathrm{WHO})^{3}$. Invasive infections caused by non-typhoid salmonella are prevalent globally, but the number of cases varies by geographical location. About $1 \%$ of enteric infections caused by non-typhoid Salmonella are complicated by bacteremia, although the true extent of bacteremia is unknown because many major enteric infections are not microbiologically diagnosed. Infants and people over the age of 65 are more likely to develop bacteremia. Concomitant diseases increase the risk of complications from bacteremia ${ }^{4}$.

Bacteriophages, or phages, are increasingly being considered as a primary or auxiliary / complementary means of combating highly resistant bacteria. Although phages have been used for therapeutic purposes in Georgia, Poland and Russia for almost a century ${ }^{5}$. However, existing commercial drugs cannot be used globally because they do not meet Western regulations and standards for pharmacological drugs. Consequently, there was a need to study bacteriophage-based preparations in more depth, taking into account their genetic, physiological and biochemical characteristics.

\section{Materials and Methods}

\section{Isolation and identification of Salmonella isolates}

The first phase of our work involved collection of non-typhoid Salmonella enterica subsp. enterica strains from different countries and from different location of pathogen habitat. Some of the strains were obtained from different countries, which were isolated from both animals and human samples with salmonellosis (feces, blood) as well as from food contaminated with Salmonella. A total of 345 strains were collected and sent to our institute for further work. 
After identification using primary, microbiological and biochemical methods, all isolates belonged to the species Salmonella enterica.

For reliable identification species of clinical isolates obtained from Georgia, Armenia and Tajikistan, were analyzed by matrix assisted laser desorption ionization-time of flight mass spectrometry (MALDI-TOF MS). The analysis revealed that 25 isolates (14 from Tajikistan, 5 from Georgia and 6 from Armenia) did not belong to the genus Salmonella. They belonged to the species: Escherichia coli (9), Hafnia alvey (5), Morganella morganii (4), Enterobacter cobay (1), Enterobacter ludwigi (1), Comamonas kerstersii (1), Citrobacter freundii (1), Citrobacter braakii 2), Proteus vulgaris (1). Accordingly, these isolates were not used for further work.

Serotyping was performed according to the White-Kaufman scheme. Of the 91 Georgian and Armenian isolates, 54\% belonged to the serotype S. Typhimurium, 32\% - S. Enteritidis and $5 \%$ could not be accurately identified, so they are referred to as - Salmonella spp ${ }^{6}$. Also, according to the Kaufman-White scheme, the strains that our laboratory received from Ireland were serotyped. Salmonella Typhimurium is the most abundant of these isolates, followed by Salmonella Dublin and Salmonella Enteritidis. The collection also includes such rare serotypes as Salmonella Uganda and Salmonella Goldcoast.

Picture № 1.

Distribution of strains used in the study by serotypes
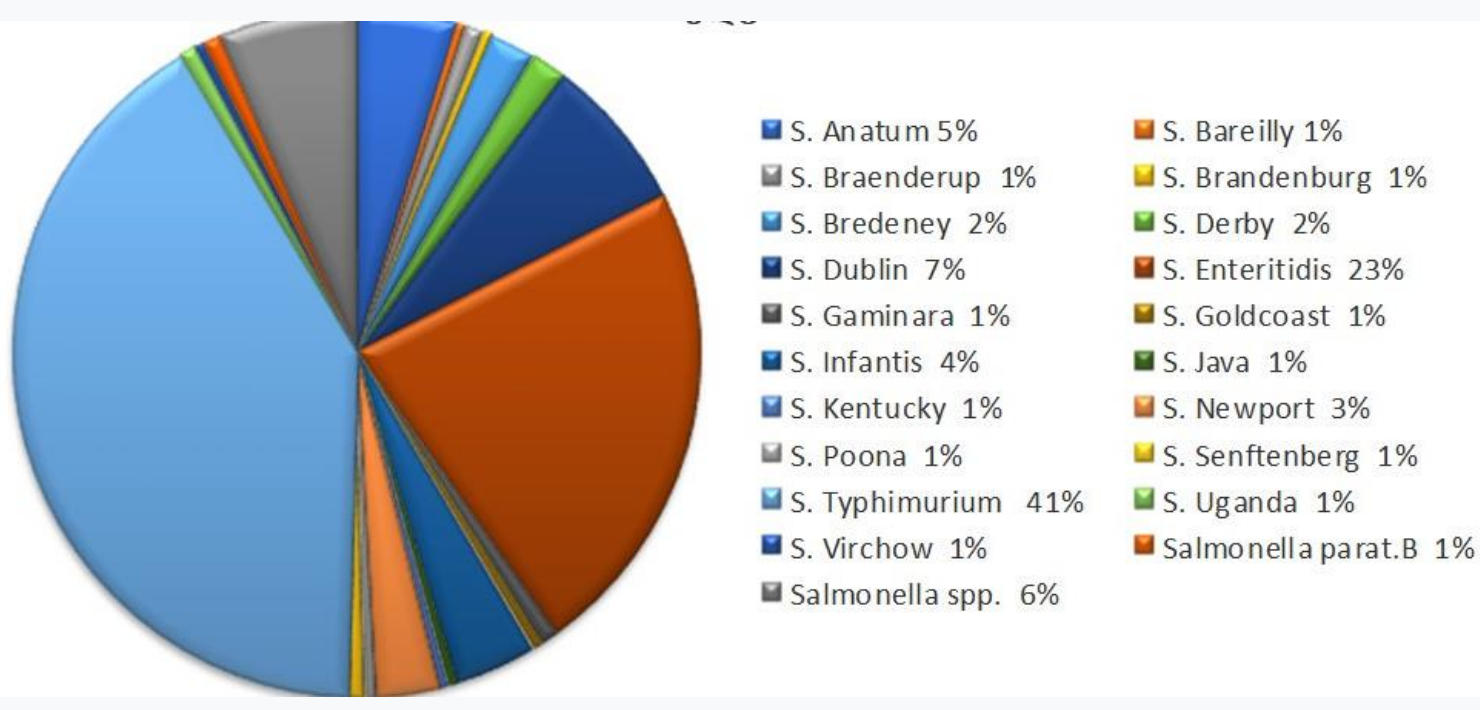

As can be seen from the picture, most of the strains (41\%) belong to S. typhimurium serotype, followed by serotype S. enteritidis - $23 \%$, serotype S. dublin - by $7 \%$, S. anatum by $5 \%$, and other serotypes by-Represented as a percentage. And unidentified serotypes, Salmonella spp. $6 \%$, S. anatum $5 \%$, while other serotypes are represented by 1 or 2 strains. (Picture 1.) 
In total, 240 strains were used in our study, of which 118 were clinical strains and about 121 were veterinary strains, including strains from Georgia, Armenia and Ireland. 148 strains from Ireland, 20 strains from Georgia, 71 - from Armenia. (Picture 2.)

\section{Picture № 2.}

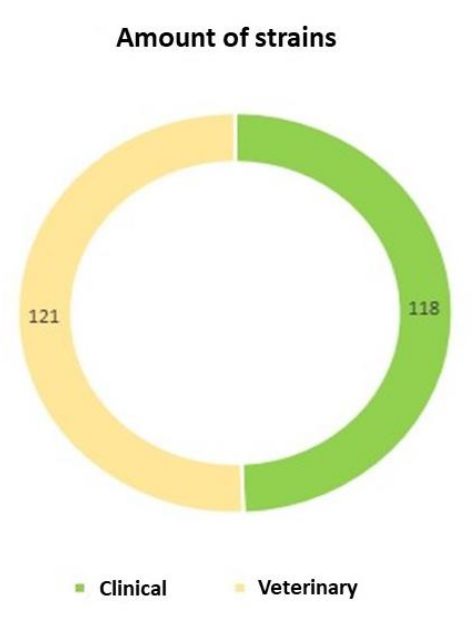

\section{Antimicrobial Susceptibility Profiles of Salmonella Isolates}

Eleven antibiotics were used to determine the susceptibility of the strains to antibiotics: ampicillin (A), amoxicillin + clavulanic acid $(\mathrm{Au})$, azithromycin $(\mathrm{Az})$, ceftriaxone $(\mathrm{Cx})$, chloramphenicol $(\mathrm{Cm})$, ciprofloxacin (Cip), nalid (Su)), streptomycin $(\mathrm{Sm})$, tetracycline (Tc), trimethoprim-sulfamethoxazole ( $\mathrm{T} / \mathrm{S})$.

As the study showed, only 3 clinical strains obtained in Georgia were found to have multiple antibiotic-resistant genotypes, 2 of these strains belong to S. Typhimurium, one - S. Enteritidis. Among them was S.enteritidis 104, which was later used to create an animal infectious model.

74.64\% of clinical isolates isolated in Armenia were found to be multidrug-resistant, of which 44 were S. Typhimurium, 5 - S. Enteritidis, 2 - S. Derby, 1 - S. Kentucky, and 1 S. Newport.

The analysis of the results showed that the highest rate of resistance is observed to Nalidixic acid (synthetic quinolone) $-68.13 \%$, the rate of resistance to other antibiotics is as follows: sulfonamide - 61.54\%, ampicillin (a Penicillin) - 52.75\%, amoxicillin + clavulanic acid $47.25 \%$, ceftriaxone (a cephalosporin) - 41.76\% and ciprofloxacin (a fluoroquinolone) $14.29 \%$. Significant amounts of isolates (13 strains) showed resistance to fluoroquinolones and third-generation cephalosporins (11 strains).

Only 9 isolates from strains isolated in Georgia and 5 isolates from strains isolated in Armenia were found to be sensitive to all antibiotics. None of the isolates were found to be resistant to all antibiotics used. The maximum number of antibiotics to which they were found to be isolated was 9, and only four isolates of S. typhimurium isolated in Armenia showed such 
high resistance. (Table №1)

Table №1

Antibiotic resistance profiles of non-typhoid Salmonella serotypes

\begin{tabular}{|l|l|l|l|l|l|l|l|}
\hline N & $\begin{array}{l}\text { Antibiotic resistance } \\
\text { Profile }\end{array}$ & MDR $^{\mathrm{a}}$ & $\begin{array}{l}\text { Number } \\
\text { of } \\
\text { isolates }\end{array}$ & $\begin{array}{l}\text { Isolate } \\
\text { identification } \\
\text { number } \\
\dagger\end{array}$ & Serotype & $\begin{array}{l}\text { Year of } \\
\text { isolation }\end{array}$ & ESBL $^{\mathrm{b}}$ \\
\hline
\end{tabular}

A) Clinical antibiotic-resistant isolates isolated in Armenia $\mathrm{n}=53$

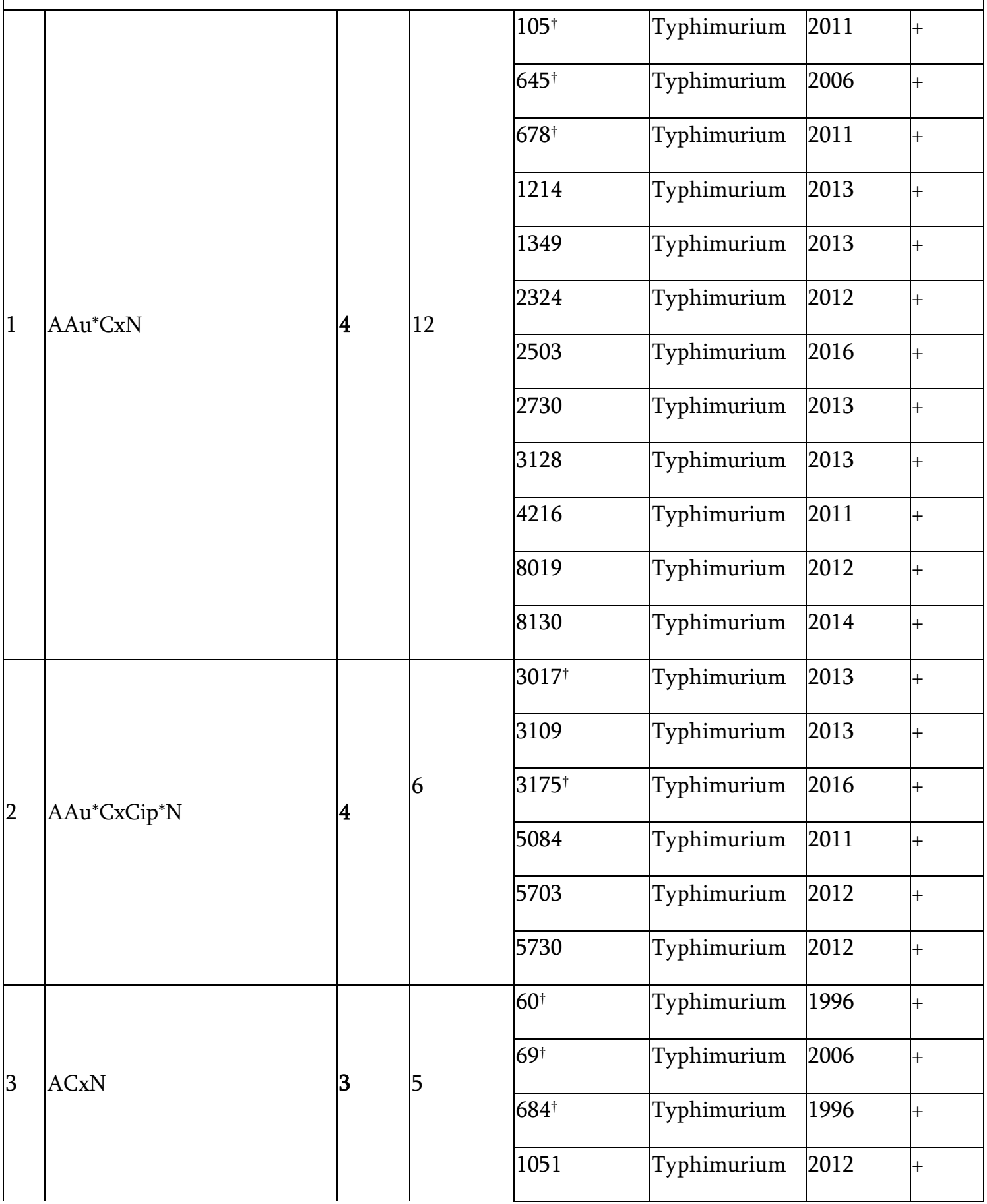




\begin{tabular}{|c|c|c|c|c|c|c|c|}
\hline & & & & 1726 & Typhimurium & 2013 & $\mid-$ \\
\hline \multirow{3}{*}{4} & \multirow{3}{*}{$\mathrm{AAu}^{*} \mathrm{CxAz}{ }^{*} \mathrm{Cip}^{*} \mathrm{~N}$} & \multirow{3}{*}{5} & \multirow{3}{*}{3} & $115^{\dagger}$ & Typhimurium & 2011 & + \\
\hline & & & & $3194^{\dagger}$ & Typhimurium & 2012 & + \\
\hline & & & & $3406 \dagger$ & Typhimurium & 2012 & + \\
\hline \multirow{2}{*}{5} & \multirow{2}{*}{ AAuCxCip*N } & \multirow{2}{*}{4} & \multirow{2}{*}{2} & $1328^{\dagger}$ & Typhimurium & 2013 & + \\
\hline & & & & 5943 & Typhimurium & 2013 & + \\
\hline \multirow{2}{*}{6} & \multirow{2}{*}{$\mathrm{AAu}^{*} \mathrm{CxCip}{ }^{*} \mathrm{NT} / \mathrm{S}$} & \multirow{2}{*}{5} & \multirow{2}{*}{2} & $6004^{\dagger}$ & Typhimurium & 2013 & + \\
\hline & & & & $8011^{\dagger}$ & Typhimurium & 2014 & + \\
\hline \multirow{2}{*}{7} & \multirow{2}{*}{ CipNSmTcSu } & \multirow{2}{*}{4} & \multirow{2}{*}{2} & $4649^{\dagger}$ & Derby & 2016 & - \\
\hline & & & & $4970^{+}$ & Derby & 2016 & - \\
\hline \multirow[b]{2}{*}{8} & \multirow[b]{2}{*}{$\mathrm{SmTcSu}$} & \multirow[b]{2}{*}{3} & \multirow[b]{2}{*}{2} & $5064^{\dagger}$ & Typhimurium & 2016 & - \\
\hline & & & & \begin{tabular}{|l}
$8239^{\dagger}$ \\
\end{tabular} & Typhimurium & 2016 & - \\
\hline 9 & $\mathrm{AAuCxAzNSmTc}{ }^{*} \mathrm{CmT} / \mathrm{S}$ & 9 & 1 & $3040^{\dagger}$ & Typhimurium & 2016 & + \\
\hline 10 & AAuCxAzNSm*Tc*CmT/S & 9 & 1 & $3725^{\dagger}$ & Typhimurium & 2016 & + \\
\hline 11 & AAuCxAzCip*NSmTc ${ }^{*} \mathrm{CmT} / \mathrm{S}$ & 9 & 1 & $3246^{\dagger}$ & Typhimurium & 2016 & + \\
\hline 12 & AAuCxAz*Cip*NSm*TcCmSu & 9 & 1 & $3889^{\dagger}$ & Typhimurium & 2013 & - \\
\hline 13 & AAuCip*NTcCmT/S & 6 & 1 & $1722^{\dagger}$ & Typhimurium & 2013 & - \\
\hline 14 & AAuCxCip*NCmSu & 6 & 1 & 3854 & Typhimurium & 2013 & - \\
\hline 15 & AAuCip*NSmCmT/S & 6 & 1 & $5923^{\dagger}$ & Typhimurium & 2011 & - \\
\hline 16 & $\mathrm{~A}^{*} \mathrm{CxNCmTcSu}$ & 6 & 1 & $5962^{\dagger}$ & Typhimurium & 2012 & + \\
\hline 17 & $\mathrm{AAu}^{*} \mathrm{CxNSu}$ & 5 & 1 & 1320 & Typhimurium & 2016 & + \\
\hline 18 & $\mathrm{AAu}^{*} \mathrm{NTc}^{*}$ & 4 & 1 & 2017 & Typhimurium & 2013 & + \\
\hline 19 & ACxCip*N & 4 & 1 & 5048 & Typhimurium & 2011 & + \\
\hline 20 & $\mathrm{NTcCm}$ & 3 & 1 & 2330 & Typhimurium & 2012 & - \\
\hline 21 & $\mathrm{AAu}^{*} \mathrm{CxNT} / \mathrm{S}$ & 5 & 1 & $126^{\dagger}$ & Enteritidis & 2011 & + \\
\hline 22 & ACip*NT/S & 3 & 1 & $588^{\dagger}$ & Enteritidis & 2016 & - \\
\hline 23 & $\mathrm{ANSm}^{*} \mathrm{Cm}$ & 4 & 1 & $6059^{\dagger}$ & Enteritidis & 2016 & - \\
\hline 24 & $\mathrm{~A}^{*} \mathrm{TcCm}$ & 3 & 1 & $6187^{\dagger}$ & Enteritidis & 2016 & - \\
\hline 25 & $\mathrm{ACx}^{*} \mathrm{CipN}$ & 3 & 1 & $7201^{\dagger}$ & Enteritidis & 2016 & - \\
\hline
\end{tabular}




\begin{tabular}{|l|l|l|l|l|l|l|l|}
26 & $\mathrm{AAu}^{*} \mathrm{Cip}^{*} \mathrm{~N}$ & $\mathbf{3}$ & 1 & $478^{\dagger}$ & Kentucky & 2016 & - \\
\hline 27 & $\mathrm{~A}^{*} \mathrm{NTm} / \mathrm{Su}$ & $\mathbf{3}$ & 1 & $7187^{\dagger}$ & Newport & 2013 & - \\
\hline
\end{tabular}

B) Antibiotic-resistant isolates isolated in Georgia, $n=3$

\begin{tabular}{|l|l|l|l|l|l|l|l|}
\hline 28 & $\mathrm{AAu}^{*} \mathrm{CxSu}$ & 4 & 1 & $104^{\dagger}$ & Enteritidis & 2016 & - \\
\hline 29 & $\mathrm{AAu}^{*} \mathrm{NCmSu}$ & 5 & 1 & $311^{\dagger}$ & Typhimurium & 2016 & - \\
\hline 30 & $\mathrm{AAu}^{*} \mathrm{SmT} / \mathrm{S}$ & 4 & 1 & $1150^{\dagger}$ & Typhimurium & 2016 & - \\
\hline
\end{tabular}

Notes: ampicillin (A), amoxicillin+clavulanic acid (Au), azithromycin $(\mathrm{Az})$, ceftriaxone $(\mathrm{Cx})$, chloramphenicol $(\mathrm{Cm})$, ciprofloxacin (Cip), nalidixic acid $(\mathrm{N})$, sulfonamide $(\mathrm{Su})$, streptomycin $(\mathrm{Sm})$, tetracycline $(\mathrm{Tc})$, trimethoprim-sulfamethoxazole (T/S).

\section{Isolation and characterizations of bacteriophages used in this study}

Isolation of Salmonella specific phages was performed using the bacterial strain enrichment method ${ }^{7}$. Ten ml of 10× concentrated lysogeny broth (LB, Oxoid Limited, Basingstoke, UK) was pipetted into a $125 \mathrm{~mL}$ Erlenmeyer flask, $90 \mathrm{~mL}$ of the water/milk sample was added and the mixture was inoculated with $1 \mathrm{~mL}$ of overnight culture of host bacteria. The flask was incubated for $18 \mathrm{~h}$ at $37{ }^{\circ} \mathrm{C}$. Then the mixture was centrifuged at $6000 \times g$ for 30 min at $4{ }^{\circ} \mathrm{C}$ and supernatant was filtered through 0.45 or $0.22 \mu \mathrm{m}$ filters and tested for the presence of phages by a spot test on bacterial streaks 8 . Overnight host bacterial cultures were diluted in the sterile LB to a final concentration of 107 colony forming units (cfu)/mL and streaks were made on $2 \% \mathrm{LB}$ agar plates using a $10 \mu \mathrm{L}$ loopful of each strain, and air-dried for 10-15 min. Ten $\mu \mathrm{L}$ of each filtered enrichment sample was applied on each streak. The plates were incubated at $37{ }^{\circ} \mathrm{C}$ for $18 \mathrm{~h}$ and phage presence was assessed based on visualization of clear spots on the bacterial growth'.

13 bacteriophages were identified and studied, of which 6 phage clones belong to the Siphoviridae family: - vB_GEC_N3, vB_GEC_N5, vB_GEC_N8, vB_GEC_M4, vB_GEC_M5

and vB_GEC_Hi; The Myoviridae family includes 6 clones: vB_GEC_Mg, vB_GEC_Bs, vB_GEC_NS7, vB_GEC_7A, vB_GEC_B1 and vB_GEC_B3; And the Podoviridae family has only one phage - vB_GEC_TR. It should be noted that among the phages used in the study, only this phage (vB_GEC_TR) was found to be a lysogenic or moderate phage.

Each phage was examined for morphological (negative colony and virion structure), biological (for host bacterial spectrum, temperature and $\mathrm{pH}$ resistance), and genetic traits. When annotating phage genomes, special attention was paid to the identification of genes that indicated the lysogenic nature of phages. For the phage genome sequence the next generation sequencing technologies were used ${ }^{10}$ 


\section{Picture №3}

\section{Transmission electron micrographs of bacteriophages used in this study}

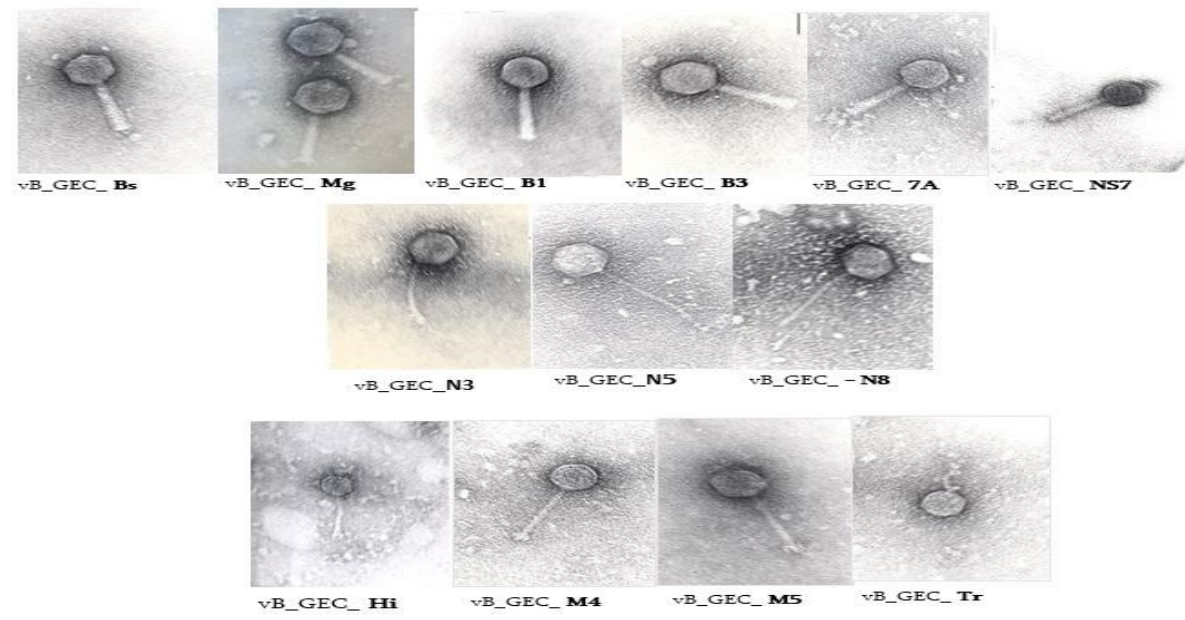

\section{Comparative characterization of phages}

In order to establish the relationship between the phages used in the study, their genomes were compared, for which we used the program - Geneious (https://www.geneious.com/). The layout of the phages on the genetic tree is as follows: They show high similarity to each other and the phages vB-GEC-B1, vB-GEC-B3, vB-GEC-NS7 and vB-GEC-7A are placed close to the genetic tree, all four of them are members of the family Myoviridae, genusFelixounavirus; Phages vB-GEC-N8 and vB-GEC-N5, both are representatives of the family Siphoviridae and genus -Tequintavirus. vB-GEC-Hi also belongs to Siphoviridae, united in the genus - Jerseyvirus, phages vB-GEC-M4 and vB-GEC-M5 are united in the same genus;

\section{Diagram №1}

Phylogenetic tree showing relatedness between phages used in the study

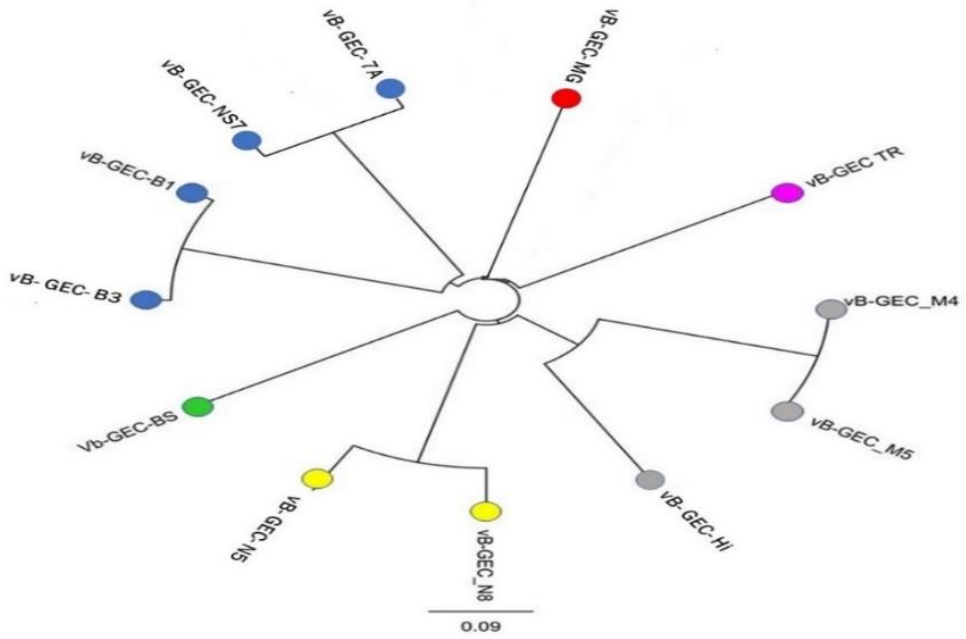

Thus, in terms of the relatedness, the phages were arranged in several groups:

1. The group of Felixounaviruses- vB-GEC-B1, vB-GEC-7A, vB-GEC-B3, vB-GEC_NS7. 
2. The group Jerseyviruses from the family Siphovoridae - vB-GEC-Hi, vB-GEC-M4 and vBGEC-M5.

3. The group of Tequinta viruses (T5 -Tequintavirus) -vB-GEC-N5 and vB-GEC-N8.

4. Genus - Tequatrovirus (T4 phages)- only one phage is representing this group - vB -GEC Mg.

5. Genus Viunaviruses - only one phage is the representative of this genus - vB -GEC -Bs.

6. Podoviridae, genus Lederbergvirus, moderate phage - vB -GEC-TR.

\section{Diagram №2}

Activity of phages used in the study against to the total number of study strains (239 strains)

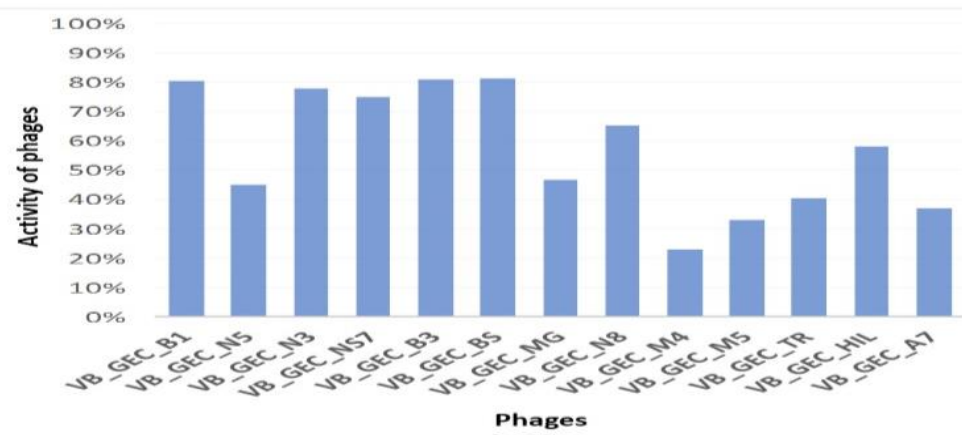

Comparison of the spectrum of action of phages used in the study revealed so-called highly active phages - vB-GEC-B1, vB-GEC -Bs, vB-GEC-B3, vB-GEC-N3, vB-GEC-NS7, vB-GECN8, the activity of which is defined from $60 \%$ to $80 \%$. (Diagram №2)

\section{Diagram №3}

\section{Activity of phages used in the study against different serotypes of the study strains}

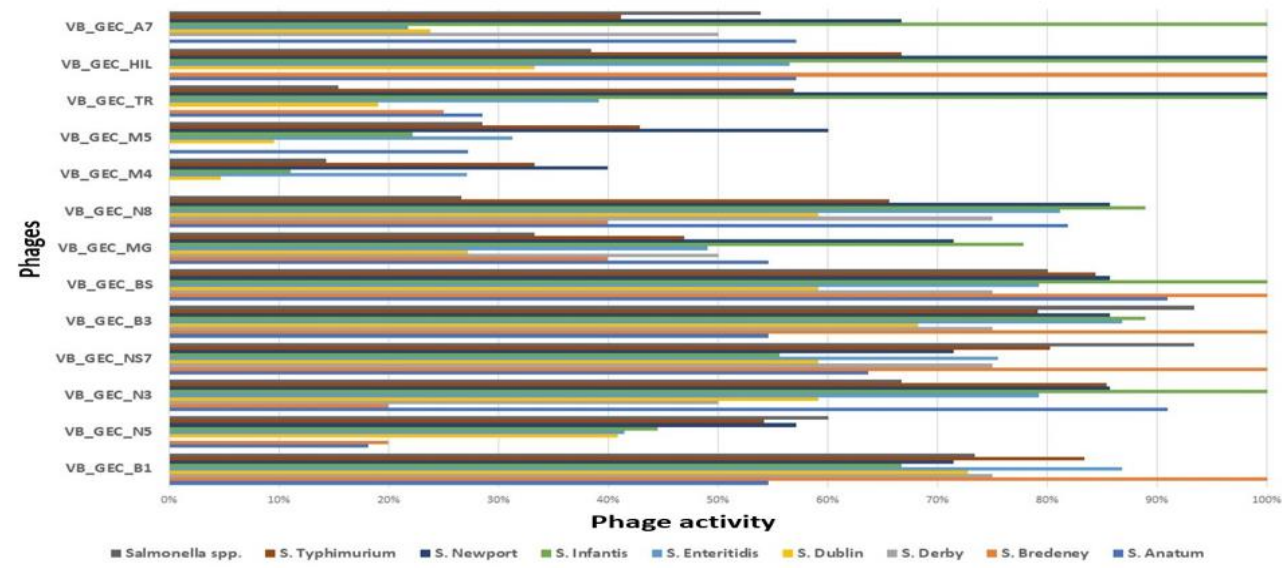

Interestingly, these phages were found to be more effective against clinical strains ( $\sim 90 \%)$ than strains of veterinary origin ( $\sim 70 \%)$. It should be noted that most of these strains which appeared to be sensitive to phages were characterized by multiple antibiotic-resistant (MDR) profiles. (Diagram №3) 


\section{Diagram №4}

Activity of phages against clinical and veterinary strains

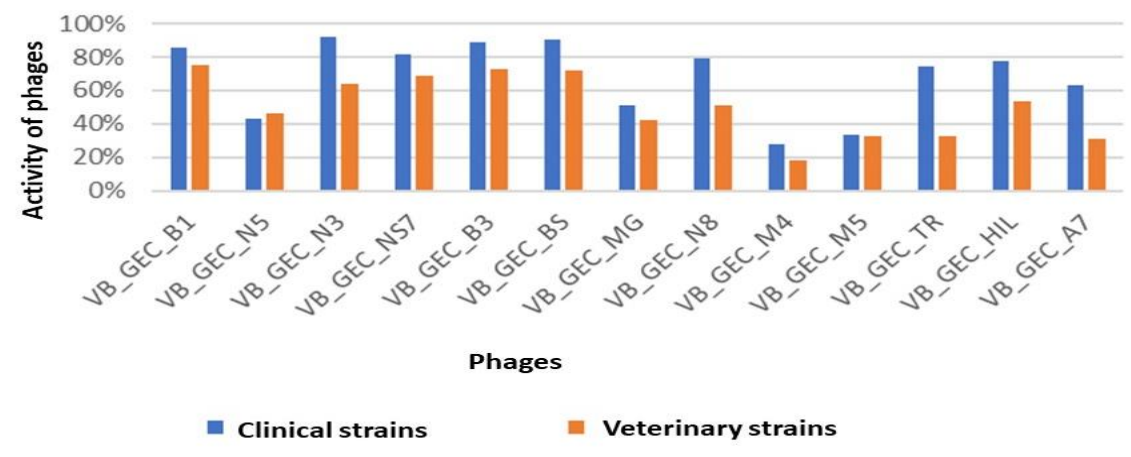

\section{Conclusions}

- From the newly isolated Salmonella specific bacteriophages - 6 belongs to the Myoviridae family - (vB_GEC_B1, vB_GEC_B3, vB_GEC_Mg, vB_GEC_Bs, vB_GEC_NS7, vB_GEC_7A), 5 - to the Syphoviridae family - vB_GEC_N5, vB_GEC_N8, vB_GEC_Hi, vB_GEC_M4,vB_GEC_M5;

- Phages with high activity are as follows - vB-GEC-B1, vB-GEC -Bs, vB-GEC-B3, vBGEC-N3, vB-GEC-NS7, vB-GEC-N8, activity of which was defined as $60 \%$ to $80 \%$;

- $\quad$ From 12 newly isolated and characterized phages 11 are lytic (virulent) phages and only one phage - vB_GEC_Tr appeared to be moderate (lysogenic);

- $\quad$ The strains that were susceptible to the phages isolated and characterized by us were mainly S. typhimurium and S. enteritidis serovars and were largely of clinical origin;

- $\quad$ Since all phages show varying degrees of efficacy against;

- $\quad 240$ antibiotic-resistant Salmonella strains'.

- $\quad$ Since our studies did not reveal any phages to which all strains were resistant and did not detect any strains to which all phages were inactive, this also indicates the possibility of using them as prophylactic / therapeutic agents;

- $\quad$ Phages are natural and specific antibacterial agents, which can lyse bacteria irrespective of their AMR status, whilst leaving the commensal microflora unharmed. This is one of the main advantages of phages in comparison to antibiotics. The phages tested in this study showed potential for application in phage therapy against MDR Salmonella infections. 


\section{References}

1. https:/www.who.int/en/news-room/fact-sheets/detail/salmonella-(non-typhoidal). Who Facts. 2018:4620869. 2.http://www.who.int/features/factfiles/diabetes/facts/en/index.html accessed on 19-06-13.

3. States U. Antibiotic Resistance Threats in US, 2013. 2013.

https://www.cdc.gov/drugresistance/threat-report-2013/pdf/ar-threats-2013508.pdf\#page $=13$.

4. Shrivastava SR, Shrivastava PS, Ramasamy J. World health organization releases global priority list of antibiotic-resistant bacteria to guide research, discovery, and development of new antibiotics. JMS - JMed Soc. 2018;32(1):76-77. doi:10.4103/jms.jms_25_17.

5. Shannon Katiyo, a Berit Muller-Pebody B, Mehdi Minaji, b David Powell, c Alan P. Johnson, b Elizabeth De Pinna, c Martin Day C, Ross Harris D, Gauri Godbolea c a. Epidemiology and Outcomes of Nontyphoidal Salmonella Bacteremias from England, 2004 to 2015. J Clin Microbiol. 2019;57(1):1-10.

6. Anna A, Iwona C, Gregorczyk P. Phage Therapy in Bacterial Infections Treatment : One Hundred Years After the Discovery of Bacteriophages. 2017:277-283. doi:10.1007/s00284016-1166-x.

7. Grimont, PAD. Weill F. Institut Pasteur - Antigenic Formulae of the Salmonella Serovars. 2007.

8. MARK H. ADAMS. Bacteriophages.

9. Mahony J, McAuliffe O, Ross RP, van Sinderen D. Bacteriophages as biocontrol agents of food pathogens. Curr Opin Biotechnol. 2011;22(2):157-163.

doi:10.1016/j.copbio.2010.10.008.

10. Makalatia K, Kakabadze E, Wagemans J, et al. Characterization of Salmonella Isolates from Various Geographical Regions of the Caucasus and Their Susceptibility to Bacteriophages. Viruses. 2020;12(12). doi:10.3390/v12121418.

11. Klumpp J, Fouts DE,Sozhamannan S. Next generation sequencing technologies and the changing landscape of phage genomics. Bacteriophage. 2012;2(3):1901-99.

doi:10.4161/bact.22111 


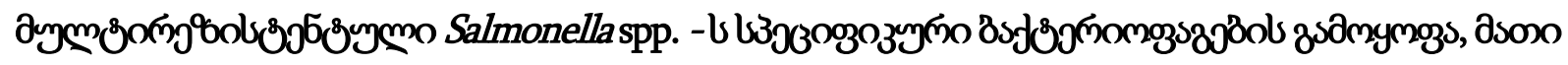

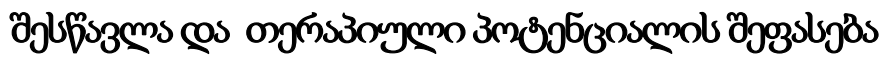

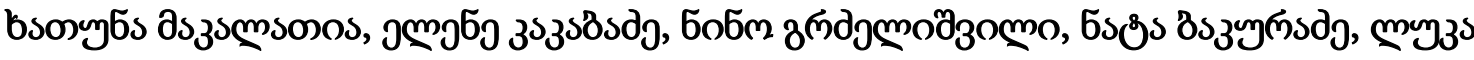

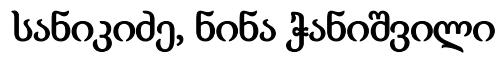

Corresponding Author: bsonybs aşకsmsonos, khatuna.makalatia@geomedi.edu.ge

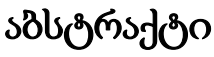

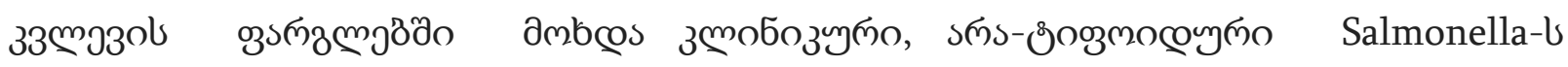

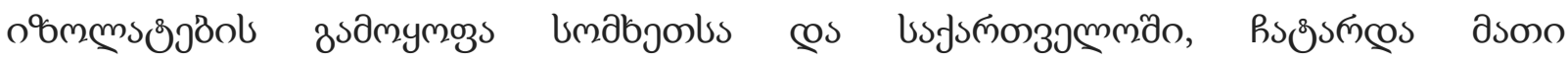

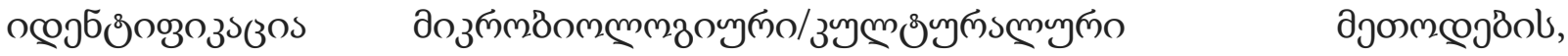

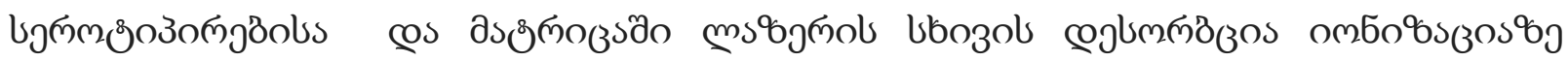

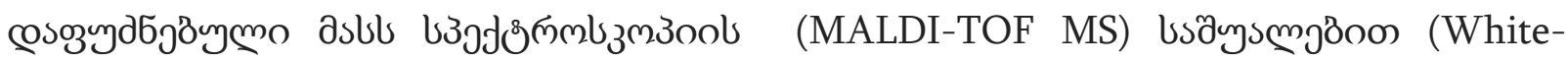

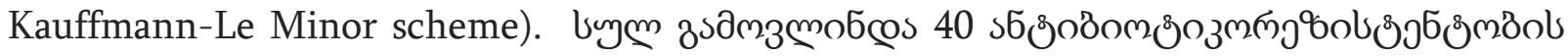

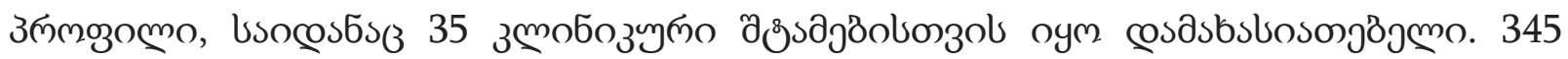

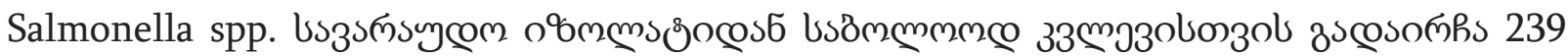

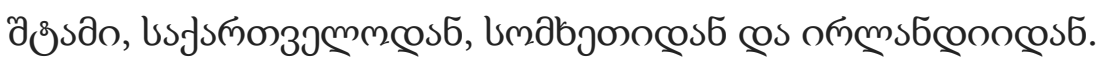

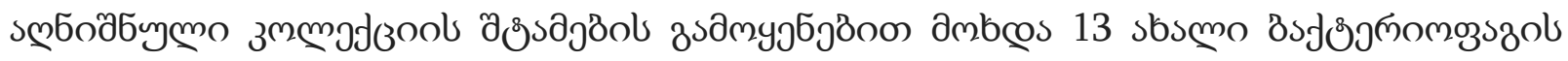

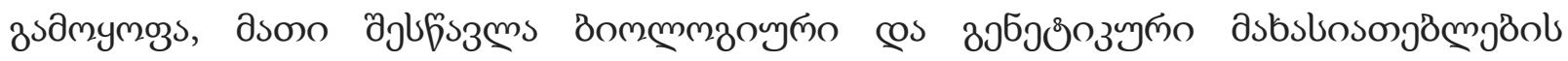

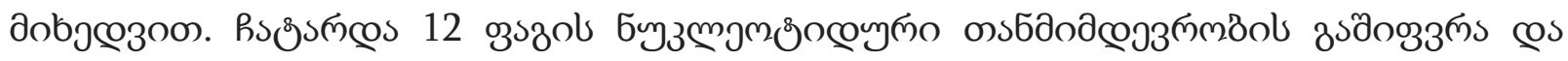

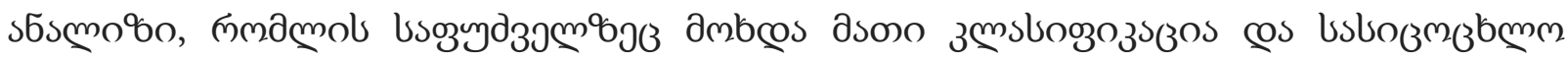

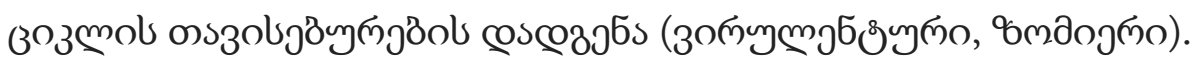

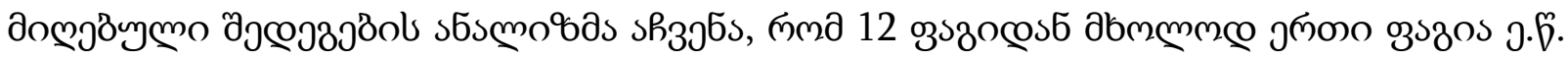

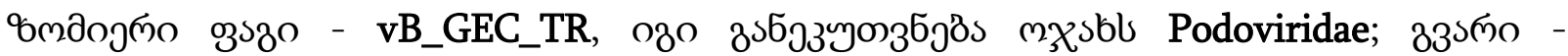

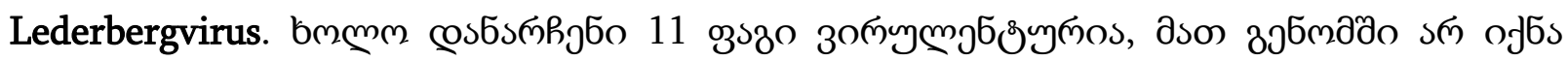

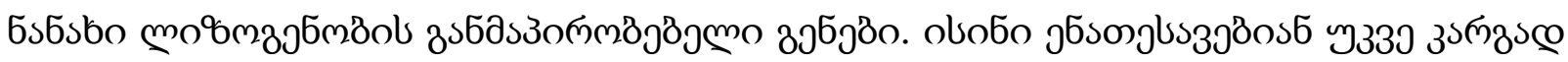

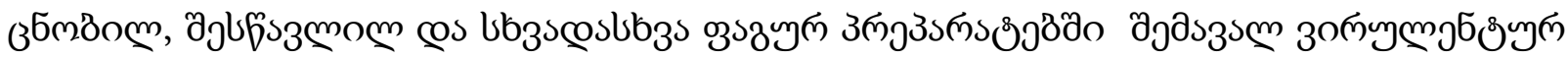

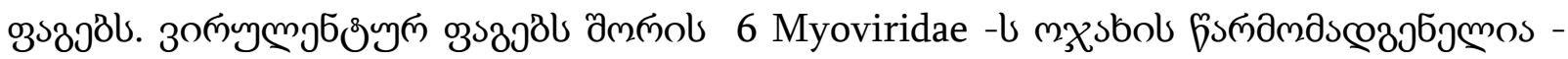
vB_GEC_B1, vB_GEC_B3, vB_GEC_Mg, vB_GEC_Bs, vB_GEC_NS7, vB_GEC_7A, bm mm 5 Syphoviridae -l mæsbol - vB_GEC_N5, vB_GEC_N8, vB_GEC_Hi, vB_GEC_M4,vB_GEC_

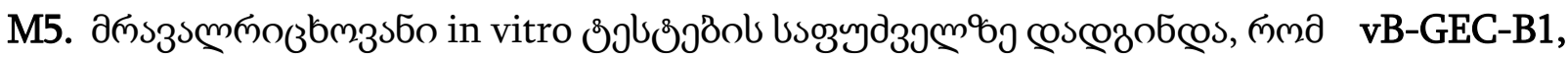

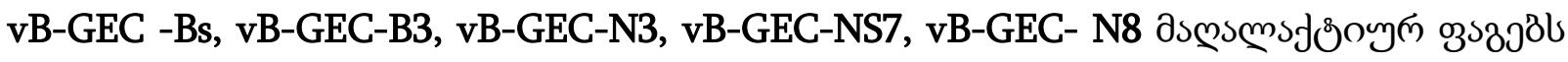

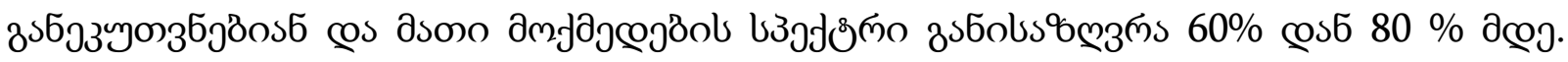

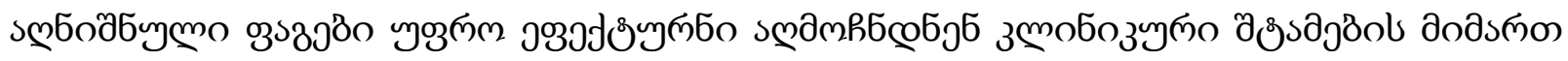

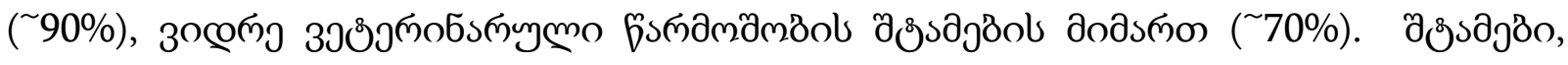

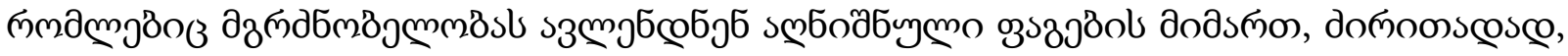

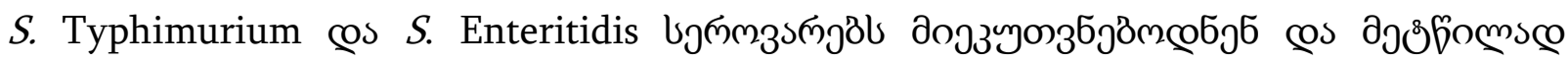

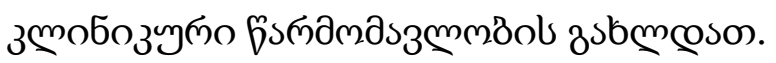




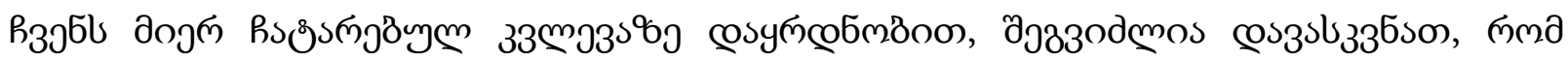

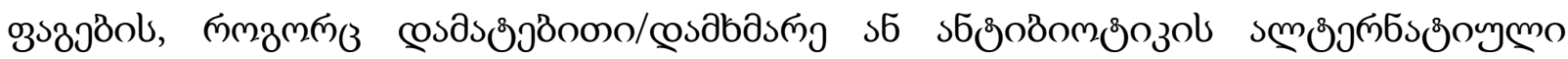
bsдy

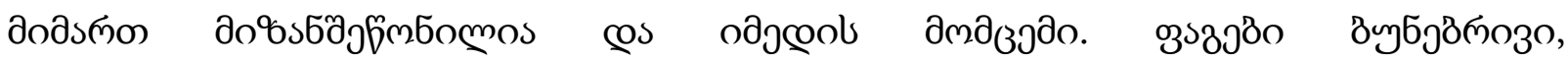

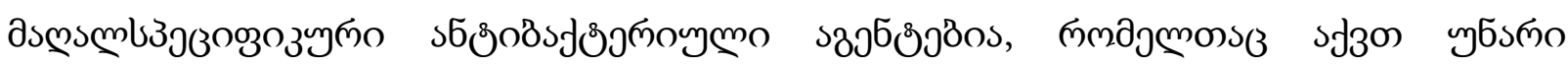

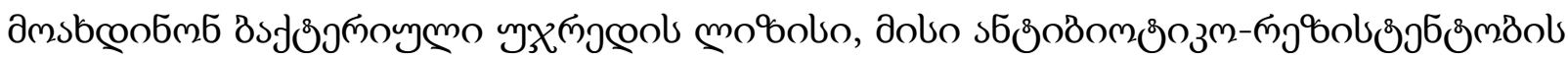

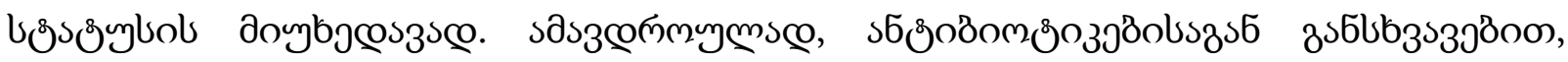

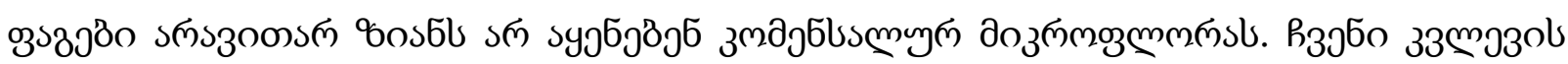

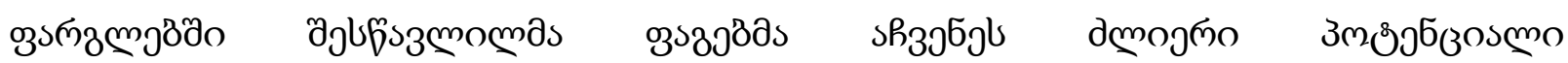

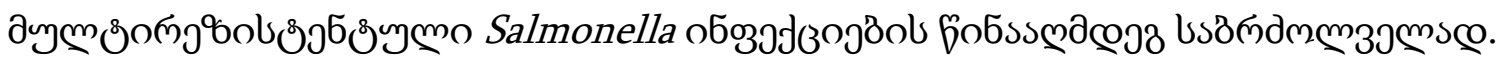

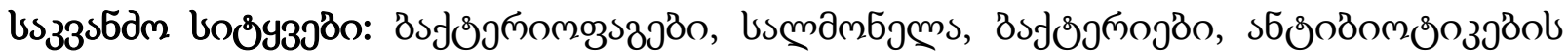

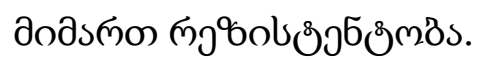

Выделение и изучение бактериофагов, специфичных в отношении Salmonella spp., с множественной лекарственной устойчивостью и оценка их терапевтического потенциала

\section{Хатуна Макалатия, Елена Какабадзе, Нино Грдзелишвили, Ната Бакурадзе, Лука Саникидзе, Нина Чанишвили}

Corresponding Author: Хатуна Макалатия, khatuna.makalatia@geomedi.edu.ge

\section{Абстракт}

В рамках исследования клинические нетифоидные сальмонеллы были изолированы в Армении и Грузии и идентифицированы на основе традиционных микробиологических методов и MALDI-TOF MS. Эти изоляты были дополнительно проанализированы путем серотипирования (схема Уайта-Кауфмана-Ле-Минора) и определены их профили чувствительности к противомикробным препаратам. Всего было идентифицировано 40 профилей устойчивости к антибиотикам, из которых 35 характерны для клинических штаммов. В конечном итоге для нашего исследования были отобраны из 345 изолятов 238 штаммов из Грузии, Армении и Ирландии.

Используя штаммы этой коллекции, выделено 13 новых бактериофагов, характеризующихся биологическими и генетическими особенностями. На основании полученных данных были классифицированы фаги и определены особенности их жизненного цикла (вирулентно-литические, умеренно-лизогенные). Анализ результатов секвенирования показал, что только один из 12 фагов, идентифицированных как умеренный фаг (vB_GEC_TR), принадлежит к семейству 
Podoviridae, род-Laderbergvirus. В то время как другие 11 фагов вирулентны, они связаны с хорошо известными и охарактеризованными фагами, которые используются в различных фаговых препаратах. Анализ их геномов не выявил каких-либо генов, связанных с лизогенией. Среди вирулентных фагов 6 принадлежат к семейству Myoviridae (vB_GEC_B1, vB_GEC_B3, vB_GEC_MG, vB_GEC_BS, vB_GEC_NS7, vB_GEC_7A) и 5 - к семейству Syphoviridae (vB_GEC_N5_M_G_G_G_M_, vB_GEC_N5_,vB_G_G_G_G_M_,vB_GEC_N5_,vB_G_G_G_M_,vB_GEC_N5_, Тесты in vitro показали, что фаги vB_GEC_B1, vB_GEC_BS, vB_GEC_B3, vB_GEC_NS7, vB-GECN8 проявили высокую активность (от 60\% до 80\%) в отношении исследуемых штаммов. Было показано, что фаги более эффективны против клинических штаммов ( $\approx 90 \%)$, чем против ветеринарных штаммов ( $70 \%)$. Штаммы, чувствительные к этим фагам, были в основном сероварами S.typhimurium и S. Enteritidis и в основном имеют клиническое происхождение. Основываясь на наших исследованиях, мы можем сделать вывод, что применение фагов в качестве дополнительного инструмента для лечения инфекций, вызываемых сальмонеллами с множественной лекарственной устойчивостью, представляется правдоподобным. Фаги - это природные и специфические антибактериальные агенты, которые могут лизировать бактерии независимо от их статуса AMR, не повреждая при этом комменсальную микрофлору. Это одно из главных преимуществ фагов перед антибиотиками. Фаги, испытанные в этом исследовании, показали потенциал для применения в фаговой терапии против инфекций, вызываемых сальмонеллами с множественной лекарственной устойчивостью.

Ключевые слова: бактериофаги, сальмонеллы, бактерии, устойчивость к антибиотикам. 